Manuscript proposed to European Early Childhood Education Research Journal:

Resubmission after minor revisions

Manuscript ID RECR-2011-0033

\title{
Early Childhood Education and Care as a space for social support in urban contexts of diversity
}

\author{
Naomi Geens \\ Michel Vandenbroeck \\ Department of Social Welfare Studies \\ Ghent University
}

Corresponding author: Michel Vandenbroeck

Michel.Vandenbroeck@UGent.be

Key words: social support, diversity, parent support, free confrontation, encounter 


\section{Abstract}

The present study illustrates that social support in ECEC settings can take place across several socio-economical and cultural borders. The presence of children as brokers of relations plays a fundamental role in the creation of social networks, in the processes of parenting support and community building. "Free confrontations" between parents and children can foster daily learning processes, despite/thanks to the contradictions and tensions that occur. This suggests that a meeting place can be a space where the experiment of democracy sporadically can emerge. In this experiment, parents, children and professionals are actors in the construction processes of parenting and community building. In so doing, parenting and living together, the pedagogical and the social, coincide.

\section{Résumé}

Cette étude montre que le soutien social peut se réaliser dans les lieux d'accueil parents enfants, au delà des barrières socio-économiques ou culturels. La présence des enfants comme déclencheurs de relations joue un rôle important dans la création de réseaux sociaux, dans le processus de soutien parental et dans la cohésion sociale. La «confrontation libre » entre parents et entre enfants favorise les apprentissages quotidiens, malgré ou grâce aux contradictions qu'elle engendre. Cela mène à penser que le lieu d'accueil parent enfants peut être un lieu ou des moments de démocratie peuvent surgir, signifiant des moments où parents, enfants et professionnels construisent la parentalité et le vivre-ensemble, là où l'éducatif et le social se rencontrent. 


\section{Introduction}

Early Childhood Education and Care (ECEC) is a social service with an economic, educative and social function (European Commission 2011). The economic function (European Parliament 2002; Plantenga and Siegel 2005) and the educative function (Heckman 2006; Leseman 2002; Penn 2009; Sylva et al. 2004) are widely documented, but attention has only recently been given to its social function (Vandenbroeck 2009a). This social function focuses on social justice issues and therefore is also concerned with parental support and social cohesion. A recent study of curricula in 15 European countries reveals that competence profiles mainly focus on children and the educational function, while they largely neglect relationships with (and especially among) parents and the social function (Urban et al. forthcoming).

The focus on parents in early childhood education is also not free from implicit assumptions about what constitutes good parenting. Parenting is not a neutral fact: it happens in specific contexts, with particular norms and values, described as parenting in context. As Gillies (2005, 836) stated, it is equally important to "challenge the notion that parenting can be separated from its socio-economic context and [...] show how the experience of living class is integral to the day-to-day process of raising children". Indeed, the context of parenting (the circumstances that influence the possibilities parents have to realise their educational projects) can differ widely. The interrelations of the context of parenting and parenting in context makes parental support a highly complex issue.

Over the last decade or so, new forms of ECEC have emerged, focussing on this social function: meeting places for parents and their children. This has been documented in England (Needham 2009), Australia (Dadich 2008), Japan (Hoshi-Watanabe et al. 2009), Italy (Musatti 
2007), France (Scheu and Fraioli 2010), Norway (Alvestad 2009) and Belgium (Vandenbroeck, Boonaert, Van der Mespel and De Brabandere, 2009). These meeting places cover a wide range of practices, regarding the people they target as well as their conceptual grounding. Some places focus on specific 'at risk' groups of parents, such as the supported playgroups in England and Australia (e.g. Dadich 2008; Jackson 2009; Nys 2008). In these cases, they are grounded in a prevention paradigm and often consider the professionals working in the meeting place as educational experts. Other places do not legitimate their work in terms of groups at risk or educational expertise. They ground their work in the social needs of parents and local communities, not assuming that parents need expert advice, but rather that they may benefit from social exchanges and encounters with peers (e.g. Rullo and Musatti 2005; Scheu and Fraioli 2010). Despite these differences, most meeting places for parents and children share a commitment towards social support and social cohesion.

Social support is one of the more salient forms of parental support. Its relevance has been widely recognised in scientific literature, for both direct effects on parents' well-being as indirect buffering effects against stress (Armstrong, Birnie-Lefcovitch and Ungar 2005; Haber et al. 2007; Kim, Sherman and Taylor 2008; Reblin and Uchino 2008) and as a bidirectional process (Sarason and Sarason 2009). Research shows that parents primarily turn to their informal social networks with questions due to a shared experience of raising children (Attree 2004; Jack 1999; Vandenbroeck et al. 2009). Hence, the promotion of informal social networks has gained momentum in policy and research (Broadhurst 2007; Hermanns 2009), albeit policy initiatives predominantly stick to parental support by experts giving advice to parents. Too little attention is paid to informal sources and practices of support between parents, whereas interactions between parents can be one of the most important sources of parenting support (Jack 1999; Sarason, Sarason and Pierce 1990). 
An important limitation of current research on social support is that it mainly focuses on 'at risk' families: single mothers (e.g. Crosier, Butterworth and Rodgers 2007), stepfamilies (e.g. Harknett and Knab 2007), teenage mothers (e.g. Gee and Rhodes 2007) or families in poverty (e.g. Hashima and Amato 1994). In doing so, research is often limited to specific categories of families, while several authors claim that social support is meaningful to all families (Broadhurst 2007), including those in positive situations/periods (Buysse 2008; Rullo and Musatti 2005; Vangelisti 2009). The narrow focus on homogeneous "at risk" groups means that diversity is all too often ignored. Yet, diversity may very well be a crucial element in informal social support as it confronts parents with diverging parenting styles and values or parental ethnotheories (Bruner 1996) and may also foster social cohesion. Through confrontation "little by little, the formal and most problematic narrative gives way to the manifold examples, anecdotes and events $[\ldots]$ yet there is no new narrative or coherence but at least the old ones are tumbling down" (Wullers 2007, 5). Musatti (2007) agrees that it is productive when codified practices disappear. Ambivalence and contradiction are welcomed (Geldof 2006; Soenen 2006) for their potential of opening up the "possibility for creative encounters and productive changes" (Braidotti 2006, 251). ECEC services can be places where free confrontation takes place: free because parents themselves decide what to do with it, but not without engagement because it makes them reflect about their way of acting anyway (Musatti 2007). Dialogue across differences opens a perspective on the messiness of human life rather than seeking, in the first instance, to resolve it (Urban 2008).

Yet, research on interactions between diverse populations frequenting ECEC services in urban settings is limited. It is often implicitly assumed that homogeneity might be a condition for effective social support. Subsequently encounters across socio-economical and cultural bounders remain out of sight, neglecting that both similarity and difference might be important (Buysse 2008; Geens 2010; Rullo and Musatti 2005; Vandenbroeck et al. 2009). It 
is also often assumed that only durable contacts, such as between intimate (or more homogeneous groups) are important in social life, and that support is conditional upon the development of relationships of trust within stable communities (e.g. Thesing Winks, 2006), thus neglecting the potential of small talk and brief contacts between 'strangers' as sources of social support and as generators of belonging (Soenen 2006). Research on informal support in ECEC is still very scarce, as parents are predominantly viewed through the lens of their child, despite the fact that some rare studies show that informal support in ECEC may be far more responsive to parents' needs than formal support (Thesing Winks, 2006). In contexts outside of ECEC, Soenen (2006) provided some interesting theoretical insights, based on observations of "small" encounters. She points a.o. at the importance of ambivalence in encounters between strangers as well as at how these interactions take place in what she call the "parochial bubble": even when a homelike atmosphere is created, the environment consist of strangers. Statements in this bubble can therefore also be considered as statements under the public gaze.

In conclusion, research on the social function of ECEC is underdeveloped, especially in relation to informal social support practices in urban settings marked by diversity. In this article we study the interactions in one meeting place for parents and children in order to uncover the feasibilities of informal social support beyond different backgrounds.

\section{Context and Methods}

Baboes is a recently established meeting place for parents and children, situated in the centre of Brussels and aiming at social support in a diverse urban context (see Vandenbroeck et al. 2009). This means that parents (or educators, since grandparents, nannies and other people bearing responsibility over the child are also welcomed) attend the centre with their child(ren) 
aged zero to five. The centre is open four half days a week and two hosts welcome the parents. Their task is explicitly not to give any educational advice, but rather to facilitate encounters. The centre is situated half way between a wealthy and a poorer area of Brussels' inner city, in what can be considered to be a "border-area" between two very different neighbourhoods. It does not aim at any specific target group, nor at any “indication”, although much attention is given to let the centre be known by all different socio-economic and cultural groups living in the area (e.g. through contacts with diverse social services and ECEC provisions, multilingual communication, visual presence in the street, ...). It is an initiative of both the child care and parent support sectors, funded by the Flemish Community in Brussels. It is a place where parenting in context occurs and thanks to the diversity of contexts of parenting, has a potential for free confrontations. The objectives of this meeting place are to offer: (1) the possibility of informal parental networks; (2) a stimulating environment for children; and (3) the promotion of social cohesion. The focus of this study was on the analysis of the daily interactions, as micro-events.

We analysed three types of data. The first set consisted of attendance registrations by the staff. Each day the staff noted the names of the child, the child's relationship with the accompanying adult and the language spoken between them. This data allowed us to look at the diversity of the families reached.

The second series of data consisted of daily reports and memos by the staff, noted in semistructured diaries, containing open questions regarding the child-child interactions, parentchild interactions and parent-parent interactions as micro-processes. The first author, selecting core themes and emblematic situations, illustrating each theme, conducted a thematic analysis of the diaries. In this thematic analysis, specific attention was given to examples of encounters crossing borders, elements of recognition, disapproval, distance and proximity, etc. The themes were subsequently checked against the diaries by the second author. Then the selected 
themes and the emblematic situations were discussed with the team, in order to conduct a more phenomenological analysis as a democratic process in which the staff was involved. In this process names and recognisable features of the selected vignettes where slightly altered in accordance with the team in order to ensure confidentiality. The period in which these two series of data was analysed (May - December 2009) covers 125 opening days, and therefore also 125 documents.

A third set of data consisted of 31 questionnaires, filled in by parents visiting Baboes during summer 2010, offering additional information on the socio-economic backgrounds of the users. Considering a response rate of $44 \%$ and the absence of data on the entire population, it was not possible to check this sample for representativity.

The combination of the three sources of data allows us to tell a "story" about the possible meanings of a meeting place for parents and children in a diverse urban context. We should bear in mind, however, that the writing of such a story can be seen as a method of discovery (Richardson 1998), yet “no permanent telling of a story can be given” (Denzin 1998, 326). Rather, "in telling a story, [we attempted] to weave a text that re-creates for the reader the real world that was studied" (Denzin 1998, 328).

\section{Results}

\section{Attendance}

From May until December 2009, 221 children from 196 families attended Baboes, with an average of 28 new children per month and 7.7 children present per opening moment, speaking 25 different languages. Approximately half of the children spoke Dutch during their first visit, $22.6 \%$ spoke French and $29.4 \%$ communicated in another language with the accompanying adult. The largest part of the visiting children was between one and two years old (54\% of all 
the visits). Yet, toddlers between three and five years of age also visited Baboes during school hours. Some of them were kept home out of medical precaution; others were not enrolled in kindergarten.

Children were predominantly accompanied by their mother (73.4\%), although in $18.8 \%$ of the visits the father joined the child (with or without another adult). Unsurprisingly fathers came more frequently on Saturdays $(32.7 \%)$. In $2.5 \%$ of the cases, a grandparent came to the meeting place and in 5.3\% there was another educator looking after the child.

\section{Insert figure 1 about here.}

The results of the questionnaire offered some additional information about the range of socioeconomic diversity. Ten parents (out of 31), worked full-time and three of them also had a full-time working partner, while half of the respondents were not working (unemployed, parental leave, housewife/man, pensioner). Eight respondents belonged to low income groups (with four of them clearly below the poverty threshold), while two users belonged to the highest income groups. Remarkably, both the poorest and the richest users belonged to oneincome families, with non-working mothers. As said before, we cannot assert that this is a representative sample of the users of Baboes, yet the sample does give an indication of its socio-economic diversity, just as the attendance data inform us about its linguistic and therefore cultural diversity. Obviously, this does not suffice to say that intercultural interactions take place or that these may be significant. Therefore a more qualitative analysis is necessary.

\section{Free Confrontation Crossing Borders}


The analysis of the daily reports provided us with some insights into what actually went on in this meeting place, as they gave many illustrations of free confrontation and interactions across languages:

Mother of Sam [30 months, sign language] communicates with the mother of Victor [4 months, Dutch] by writing things down and with sign language. She says she has a sister in Hungary. The mother of Victor tells about his father who did a moonlight flit, back to Spain.

In the meeting place, parents talk to each other in a shared language, via notes, making use of gestures or with a third person as 'instant-translator'. A shared experience or the possibility to share an experience, urges people to bridge the language gap. This kind of communication goes beyond daily exchanges and stories are shared. What starts with small talk often evolves into more in-depth discussions, creating a sense of belonging. Children are not infrequently the brokers of the contacts between parents The confrontation with different ways of acting can foster reflection on a person's own way of upbringing. Also observing one's own child in a different environment, can generate new insights:

A mother, who always kept her child out of day care, doubts her decision when seeing him interact with other children. She says: "I think Tuur [17 months, Dutch] should go to a day care centre".

It is not so important what the mother finally decided, but the opening up of discussion - and thus the acceptance of contradiction - may be supportive.

Gender constructions, as another aspect of diversity, were confirmed and contested in the daily interaction in Baboes:

Professional: "That is men's work". 
Mother with headscarf [reacts] laughing: "That's not always true. Sometimes, women can do this better."

Professional says to the mother of Rahim [52 months, Arabic]: "maybe he will be cooking a meal for you in some years".

Mother answers "no". She tells that men [in her native country] are being served.

Adults were not alone in discussing gender issues, children also played it in their games. Some parents stimulated their children to play with specific toys, while others did not accept that their child took part in a 'gendered' game:

Father of Samir [30 months, Arabic], Arabic speaking man, approximately 50 years old, stimulates his son to play in the kitchenette. After 10 minutes, Samir plays in the kitchenette until closing time. His father joins him in his game - very nice! At a certain moment, everybody gathers at the ball pit. Samir does not turn away from the kitchenette and continues his play. On parting, Samir gave Lander [26 months, Dutch] a hand, and one minute later two kisses (after Samir's father said something to him) [previous to that, there was a small conflict between the two boys].

"That's for girls, dad does not allow this", father of Robbe [20 months, Dutch] reacts to his son when he started pushing a buggy.

The observations suggest that contradictions are possible and that they do not necessarily lead to conflicts. ECEC can be considered as broadening the educational space: both parents and children come into contact with other/new roles. How they experience this contact (as a confirmation, enrichment, contradiction) is diverse and variable. 


\section{Space and the Other}

In the daily reports, we read illustrations of how physical boundaries were crossed and people or stories were symbolically brought into the meeting place, even when they were living on the other side of the world:

Samir [29 months, Arabic] on the phone. The professional asks who he is talking to. He says "Mami". His mother explains that it is his grandmother. Samir says: "Mami, I am at Baboes, you have to come". "Samir likes his grandmother very much", adds his mother.

Mother of Omar [24 months, Urdu] points at her native region on the globe and explains that she moved from there to Belgium 10 years ago as a result of her marriage. Her family is still living in her native country. It is the first time (after many visits) that she directly addresses the staff.

The telephone conversation is not just a game, it is Samir's way of expressing himself about Baboes. It is a meaningful action, an invitation from Samir to a person who is probably very precious to him. Samir also wants to share his experience with persons who are not physically present. The design of the meeting place is an important mediator to support or obstruct this, depending on its tempting character and most importantly, due to the presence of a listener, of $\mathrm{a}$ - for children sometimes imaginary - public to tell their story to. The presence of other persons in the meeting place makes it possible for the mother of Omar to share her story. It is a sensitive topic and the globe functions as an available mediator. The meeting place offers the possibility to be present in different ways, in different roles and to shift from one role to another. 
The other in the meeting place can be a listener, but also a 'commentator'. The intention of the comments made by one person and the interpretation of it by the other, can vary widely: they can be read in many ways. The following quote from a diary illustrates this:

Fabio [54 months, Italian] remarks on a boy, named Lars [29 months, Dutch], who is extremely silent and never communicates with other children. He says: "In my class, there is also a Lars, but he speaks for real".

Fabio's remark on the quietness of Lars can be considered as disapproval, but on the other hand it can be seen as recognition of Lars being in the meeting place, by naming him. This is also an example of free confrontation between children (and possibly parents watching them). It suggests that free confrontation is not exclusively for adult interaction.

Parents often remark on their child's behaviour. Their statements can be viewed as relections on reality, but also as something acted out in public or for a certain listener.

Lars [28 months, Dutch] is playing with the cars. Bo [18 months, Dutch] also takes one.

Lars holds out his hands to regain the car. Lars' mother says that he has to share, that the toys are for all the children.

The reaction of the mother to her son reflects her idea about 'good parenting', or what she is expected to say as 'a good mother' in the gaze of the others. This suggests that the meeting place is not a private place like the home, but a public (or parochial for that matter) place of socialisation. The meeting place is a social space where interaction takes place in the presence of (unknown) others. There are several examples where parents legitimated their own behaviour or that of their child, being very conscious about the presence of the other:

"Before anyone gets wrong thoughts: I am the father, and she is the grandmother." 
Anouk [17 months, Dutch] is crying because another child is playing with something she wants to play with. She finds it difficult to share things. Her mother says that she is tired.

A grandmother is reading a book about chocolate to her grandchild Lotte [24 months, Dutch]. She adds to the story that chocolate gives you a sore stomach. Then she looks up and says "I can not resist making it educative".

The last fragment is a striking example of how the grandmother became aware of her own norms and values, realising that others were watching her. By hearing her own words, she realised that others interpret how she looks at chocolate and children's learning. This understanding made her apologise, as if she believed that someone could blame her for this. From a concern that someone could misunderstand one's actions, parents try to intervene actively by explicit communication. In some cases, this 'gaze of the other' was used as pressure to regulate the behaviour of the child:

"[The professional] will not be proud of you”, says the mother of Bo [22 months, Dutch] to her when she did not want to sit in the buggy. [The professional] is frustrated because he did not react.

“Everybody will look at you!” Mother of Lars [29 months, Dutch] and Ilona [3 months] to her son after he is crying because they have to go home. Yet, Lars has difficulties with being watched. [Only the two professionals are still in the meeting place].

\section{Multiple Identities: A Dynamic Construction}

All parents visiting Baboes, share the parenting experience. They are all a parent (or educator) but also Italian or Japanese, workman or housewife, brother or daughter and so on. 
Individuals have multiple identities, the unique composition of the life story of a person, entails encounters, based on sameness and difference. Identities are dynamic: one moment a person can talk as a single parent to another single parent, the next moment the person can direct a child in their native language, subsequently that person can make a telephone call with a colleague. These multiple identities make it possible to transcend aspects of identity (like ethnic background). Parents frequenting Baboes can approach each other based on a common identity of being a father, a parent, or an inhabitant of Brussels. Moreover, this interaction based on commonality can form the pre-set of addressing the other as Flemish, French or Moroccan. On the one hand, recognition can be a first step for further contact, from the assumption that someone with a similar characteristic shares the same kind of experience:

"Yes, it's a baby like you", says the father of Clement [13 months, French] when Clement is looking for contact with another 'coloured'child. Clement was adopted.

A Portuguese and a Japanese mother are having a conversation about what it is like to follow a beloved person to Belgium. The mother of Kai [19 month, Japanese] would like him to learn the German language (which he does not speak) because he has Germanand only German - nationality.

"I heard that twins of the same gender are more often jealous", mother of Lien [19 months, Dutch] and Sara [19 months] to the mother of Taamir [52 months, Urdu], Rashid [52 months] and Farah [28 months].

Seemingly obvious thoughts are being questioned in the contact with other people, traditions, habits, perspectives and so on. This offers the possibility to look at oneself in different ways, or to confirm present opinions about oneself and the child: 
"I do not see my child this happy at home", a mother tells about her child's tantrums and declares that she finds it difficult to cope with.

"They have this in the childcare centre too, but I did not see her playing with it before", mother of Marie [24 months, Dutch] about the kitchenette.

"I am very happy", mother of Misaki [22 months, Japanese] is touched when she sees her daughter asking to be taken up by the mother of Anouk [19 months, Dutch]. She never did this before and used to be afraid of other adults.

"He's getting taller", mother of Aran [16 months, Thai] realises that the table becomes a potential danger, now her son is getting taller. Some time ago, Aran was too little to hit the corners of the table.

\section{Parenting as a Shared Responsibility}

To intervene in interactions of other parents is a delicate issue. However, when the safety of a child is in danger, other parents can feel urged to act. In a way, this concern justifies the intervention a priori.

When the mother of Victor [2 months, French] wants to leave and takes her baby carrier, she leaves Victor alone on the sofa. The mother of Floor [3 months, Dutch] is worried and gets up to keep an eye on Victor. When his mother returns, she says: "This is dangerous". The mother of Victor says that he is not moving yet. The mother of Floor replies that this can suddenly happen and she gives an example about her son. 
The remark that the mother of Floor made about the behaviour of the mother of Victor, can be interpreted in a negative way, but at the same time, she was worried about Victor's safety. This is not only an example of contradiction, but also of the social aspects of parenting. As a parent, it is almost impossible (and undesirable) to watch every step of one's own child(ren) and simultaneously each parent sees other children acting.

Each interaction consists also of a learning component, for example: a parent who considers the own way of acting as correct, but is confronted with a remark on this acting (in this case from a safety point of view), may take this along in further action. On the other side, the parent who made the remark could be inclined to reconsider their perspective. These are illustrations of free confrontation: free indeed, but not without engagement. It is not only the behaviour of others that activates reactions, also verbal disagreement arises, not necessarily linked with behaviour in the meeting place.

A conversation between two fathers: about living in Brussels (and the differences with Amsterdam) and about the age that children go to school. For example, the father of Chiara [23 months, Dutch] finds it important that children can play for a long period and can discover things (like in the Netherlands where toddlers go to school at the age of four; and in the native country of his wife at the age of five). The father of Anouk [18 months, Dutch] prefers the system in Belgium, where it is possible to start school from the age of 2.5. He argues: the younger they can learn, the better.

This kind of contradiction is not exclusive to conversations in a meeting place; it can also take place at the school gate or in the living room. But, the richness of interactions in the meeting place resides in the possibility to meet and talk to people other than those of people's own social network, the latter consisting more often of a homogeneous group. The input from persons with very diverse backgrounds and experiences is not always self-evident, but enhances "disagreement" and therefore confrontation and reflection. 


\section{Discussion}

Given that the social function of ECEC is still underdeveloped, the daily interactions in the Baboes meeting place were studied as micro-events (Vandenbroeck et al. 2009) in order to uncover the feasibilities of informal social support practices across different socio-economic and cultural backgrounds. The attendance data show that it is feasible to serve a cultural and socio-economic diverse group of parents and children.

The qualitative data revealed that these diverse groups interacted, crossing several borders. The (inter)actions can be situated between appreciation and disapproval; differences and similarities; distance and proximity. Confrontations occurred both in verbal and non-verbal ways and were often mediated by the children. The presence of children as brokers of relations plays a fundamental role in the creation of social networks, in the processes of parent support and in social cohesion, as also noted by Soenen (2006).

Rourou et al. (2006) state that multicultural child centres can offer good opportunities for young children from diverse cultural backgrounds to learn to play together and to solve their conflicts in constructive ways, yet mutual understanding between parents does not develop automatically. The meeting place is a space where children, parents and staff learn from the interaction: in meeting others, we learn to know ourselves (or we are urged to look at ourselves more carefully). Nealon (1997) points out that space for multivocality is important. The presence of professionals as facilitators of encounters and of diversity in the meeting place, plays a significant role in the occurrence of free confrontation. The meeting place is a social sphere where norms and values are negotiated in the daily interactions between parents, children and professionals. In the free confrontation, participants are free to (re)act, but takenfor-granted assumptions are inevitably questioned through daily micro-interactions. It may 
foster daily learning processes, despite/thanks to the contradictions that occur. In an open, unconstrained environment, contradictions may very well be supportive (Vandenbroeck et al., 2009), as parents construct themselves in the mirror of sameness and difference.

Meeting places can be spaces where democratic moments emerge (Biesta 2011), depending upon the open character of the meeting place, on the presence of a diversity of perspectives, on the openness to speak and be listened to. Noens and Ramaekers (2011) underline that the meeting place should be unconditional and a place where there is room for the everyday aspects of parenting. Parents should remain the first owner of their parenting project and not be reduced to spectators of their own situation, weighed down by the dominant discourse about what good parenting is (Bouverne-De Bie 2005). According to Biesta (2011) democracy is not about following or incorporating a set of norms and values, but goes beyond this order, constructing something new over and over again. He calls this "subjectification". In this sense, parent support is not informing parents about 'the good ways of parenting', but creating space (as a quality of atmosphere) for parents to reflect with each other about their practices and what they find important to offer their children in their education project. According to Biesta it is an engagement in the experiment of democracy. In this experiment, parents, children and professionals are actors in the construction of parenting as well as of social cohesion. This may mean that parenting and living together - the pedagogical and the social meet.

We acknowledge that this study is a description of only one meeting place, and as stated before, meeting places can substantially differ regarding their users and their goals. Further, our study is largely based on observations by the staff, rather than by the researchers. Therefore, this analysis is only tentative and provisional. Nevertheless, it illustrates that social 
exchange in ECEC settings across socio-economical and cultural borders, is feasible, yet not self-evident. Childcare centres are also services where diverse parents meet. In affluent countries, today the majority of parents will make use of some form of out-of-home childcare (UNICEF 2008). This offers unique opportunities for a large population of diverse families to encounter, if the social function of ECEC is seriously taken into account and efforts are made to open the doors to all families.

We cannot take for granted that productive meetings will occur and are experienced as supportive. Indeed, motivations and contexts of parents using day care centres or kindergarten may differ from those of parents in meeting places. Consequently, further research on interactions between parents and their meaning is necessary, as this area of research is only beginning to be explored (Thesing Winks, 2006). For such research, it may be important to take into account the lessons learned from meeting places, without formalising this concept into a method, since it is exactly its unconditional atmosphere, the openness for dis-order that generates opportunities for exchange.

We argue for a broad perspective on childcare as a social service, that integrates the economic, educative and social function. Among other things, it should create a space for encounters between a diversity of families.

\section{Acknowledgements}

The present study was made possible thanks to the funding of the VGC (Commission of the Flemish Community in Brussels) and Minister Brigitte Grouwels. We are grateful for their support and their confidence. We also wish to thank the coordinator and the staff of Baboes for their trust and their openness. 


\section{References}

Alvestad, M. (2009). Early childhood education and care policy in Norway. European Early Childhood Education Research Journal 17(3): 416-424.

Armstrong, M.I., Birnie-Lefcovitch, S. and Ungar, M.T. (2005). Pathways between social support, family well being, quality of parenting, and child resilience: what we know. Journal of Child and Family Studies 14(2): 269-281.

Attree, P. (2004). Parenting support in the context of poverty: a meta-synthesis of the qualitative evidence. Health and Social Care in the Community 13(4): 330-337.

Biesta, G. J. J. (2011). Learning democracy in school and society: Education, lifelong learning and the politics of citizenship. Rotterdam: Sense Publishers.

Bouverne-De Bie, M. (2005). Over respect voor gezinnen en gezinsgericht werken. In Gezin en opvoeding: weldadig en gewelddadig (eds) H. Van Crombrugge and E. Lombaert, 6176. Antwerpen/Appeldoorn: Garant.

Braidotti, R. (2006). Affirmation versus vulnerability: on contemporary ethical debates. Canadian Journal of Continental Philosophy 10(1): 235-254.

Broadhurst, K. (2007). Parental help-seeking and the moral order. Notes for policy-makers and parenting practitioners on 'the first port of call' and 'no one to turn to'. Sociological Research Online 12(6). Retrieved 3/12/2009 from www.socresonline.org.uk/12/6/4.html

Bruner, J. (1996). The culture of education. London: Harvard University Press.

Buysse, A. (2008). Opvoedingsondersteuning. Ondersteuning van gezinnen vandaag : een onderzoek. In opdracht van de Vlaamse Gezinsbond. UGent, Faculteit Psychologie en Pedagogische Wetenschappen, Vakgroep Experimenteel-klinische en Gezondheidspsychologie. 
Crosier, T., Butterworth, P. and Rodgers, B. (2007). Mental health problems among single and partnered mothers. Social Psychiatry 42: 6-13.

Dadich, A. (2008). Evaluating playgroups: an examination of issues and options. The Australian Community Psychologist 20(1): 95-104.

Denzin, N. K. (1998). The art and politics of interpretation. In Collecting and interpreting qualitative materials (eds) N. K. Denzin and Y. S. Lincoln, 313-344. London: Sage Publications.

European Commission (2011). Early childhood education and care: Providing all our children with the best start for the world of tomorrow. Brussels: Communication from the Commission.

European Parliament. (2002). Presidency conclusions. Barcelona European Council. 16 March 2002. Brussels: European Parliament and Council.

Gee, C. B. and Rhodes, J. E. (2007). A social support and social strain measure for minority adolescent mothers: A confirmatory factor analytic study. Child Care, Health and Development 34(1): 87-98.

Geens, N. (2010). Sociale steun en vrije confrontatie in Baboes, een ontmoetingsplaats voor kinderen en ouders. Onuitgegeven meesterproef. Promotor: M. Vandenbroeck. Gent: Vakgroep Sociale Agogiek, UGent.

Geldof, D. (2006). De stad is een kosmos. Alert 32(3): 67-79.

Gillies, V. (2005). Raising the 'meritocracy': parenting and the individualization of social class. Sociology 39(5): 835-853.

Haber, M. G., Cohen, J. L., Lucas, T. and Baltes, B. B. (2007). The relationship between selfreported received and perceived social support: a meta-analytic review. American Journal of Community Psychology 39: 133-144. 
Harknett, K. and Knab, J. (2007). More kin, less support: Multipartnered fertility and perceived support among mothers. Journal of Marriage and Family 69: 237-253.

Hashima, P. and Amato, P. (1994). Poverty, social support, and parental behavior. Child Development 65: 394-403.

Heckman, J. J. (2006). Skill formation and the economics of investing in disadvantaged children. Science 312(5782): 1900-1902.

Hermanns, J. (2009). Het opvoeden verleerd. Amsterdam: Vossiuspers UvA.

Hoshi-Watanabe, M., Kamigaichi, N., Shiozaki, M. and Mukai, M. (2009). Les lieux de soutien d'éduquer les enfants au Japon. Unpublished work document.

Jack, G. (1999). Ecological influences on parenting and child development. British Journal of Social Work 30: 703-720.

Jackson, D. (2009). A place to be: the role of supported playgroups in creating responsive, social spaces for parent and child wellbeing. Unpublished PhD. Sydney: University of Western Sydney.

Kim, H. S., Sherman, D. K. and Taylor, S. E. (2008). Culture and social support. American Psychologist 63(6): 518-526.

Leseman, P. (2002). Early childhood education and care for children from low-income or minority backgrounds. Paris: O.E.C.D.

Musatti, T. (2007). La signification des lieux d'accueil pour la petite enfance aujourd'hui. In ouveau paradigmes pour repenser l'éducation préscolaire (eds) G. Brougère and M. Vandenbroeck, 207-224. Brussels: Peter Lang.

Nealon, J. T. (1997). The ethics of dialogue: Bakhtin and Levinas. College English 59(2): $129-148$

Needham, M. (2009). Learning to learn in supported parent toddler groups: A sociocultural investigation. Unpublished PhD. London: University of London. 
Noens, P. and Ramaekers, S. (2011). Opvoedingsondersteuning in ontmoeten: Onderzoeksverslag ter ontwerp van een bronnenboek. Leuven: Laboratorium voor Educatie en Samenleving, K.U.Leuven.

Nys, K. (2008). Ouders in perspectief. Doctoraatsproefschrift. Leuven: KUL.

Penn, H. (2009). Early childhood education and care. Key lessons from research for policy makers. Brussels: Nesse.

Plantenga, J. and Siegel, M. (2005). Position paper "Childcare in a changing world". Part 1: European childcare strategies. Groningen: Rijksuniversiteit Groningen.

Reblin, M. and Uchino, B. N. (2008). Social and emotional support and its implication for health. Current Opinion in Psychiatry 21: 201-205.

Richardson, L. (1998). Writing: a method of inquiry. In Collecting and interpreting qualitative materials (eds) N. K. Denzin and Y. S. Lincoln, 345-371. London: Sage Publications.

Rourou, A., Singer, E., Bekkema, N. and De Haan, D. (2006). Cultural perspectives on peer conflicts in multicultural Dutch child care centres. European Early Childhood Education Research Journal 14(2): 35-53.

Rullo, G. and Musatti, T. (2005). Mothering young children: Child care, stress and social life. European Journal of Psychology of Education 20(2): 107-119.

Sarason, B. R., Sarason, I. G. and Pierce, G. R. (1990). Social support: an interactional view. New York: John Wiley \& Sons.

Sarason, I. G. and Sarason, B. R. (2009). Social support: mapping the construct. Journal of Social and Personal Relationships 26(1): 113-120.

Scheu, H. and Fraioli, N. (2010). Lieux d'accueil enfants parents et socialisation(s). Strasbourg: Le Furet. 
Soenen, R. (2006). Het kleine ontmoeten. Over het sociale karakter van de stad. Antwerpen/Apeldoorn: Garant.

Sylva, K., Melhuish, E., Sammons, P., Siraj-Blatchford, I. and Taggart, B. (2004). The effective provision of preschool education (EPPE) project: Final report. Nottingham: DfES Publications - The Institute of Education.

Thesing Winks, A. (2006). Support for mothers by early childhood centres: a qualitative study. A thesis for a doctorate in education. Palmerston North: Massy University.

UNICEF (2008). The child care transition, Innocenti Report Card 8. Florence: UNICEF Innocenti Research Centre.

Urban, M. (2008). Dealing with uncertainty: challenges and possibilities for the early childhood profession. European Early Childhood Education Research Journal 16(2): 135152.

Urban, M., Vandenbroeck, M., Lazarri, A., Peeters, J. and Van Laere, K. (forthcoming). Competence requirements in early childhood education and care. London - Ghent: UEL UGent.

Vandenbroeck, M. (2009a). In verzekerde bewaring. Honderdvijftig jaar kinderen, ouders en kinderopvang. Tweede volledig bijgewerkte druk. Amsterdam: SWP.

Vandenbroeck, M. (2009b). Let's disagree. European Early Childhood Education Research Journal 17(2): 165-170.

Vandenbroeck, M., Boonaert, T., Van der Mespel, S. and De Brabandere, K. (2009). Dialogical spaces to reconceptualize parent support in the social investment state. Contemporary Issues in Early Childhood 10(1): 66-77.

Vangelisti, A. L. (2009). Challenges in conceptualizing social support. Journal of Social and Personal Relationships 26(1): 39-51. 
Wullers, D. (2007). Reading the city, appreciating the neighbourhood: the case of Linkeroever, Antwerp. 43rd ISOCARP Congress. 